\title{
PEMANFAATAN BATU-BATUAN KECIL ( KERIKIL JAGUNG ) SEBAGAI BAHAN TAMBAH PEMBUATAN PAVING BLOCK
}

\author{
Sri Wardani , Drs. Prihantono, M. Eng, Ir. Tri Mulyono, MT,
}

\section{PENDAHULUAN}

Kebutuhan akan bahan bangunan, setiap tahun selalu meningkat. Salah satunya adalah Paving Block. Untuk mendapatkan Paving Block yang berkualitas baik adalah dengan cara menambah bahan lain untuk menyusun komposisi campurannya.

Salah satu bahan yang memberi kemungkinan sebagai bahan pembuatan Paving Block adalah batu-batuan kecil (Kerikil Jagung). Batu-batuan ini dapat diperoleh dari penyaringan pasir batu (sirtu) / dari penyaringan pasir kasar yang mengandung batu-batuan kecil.

Berdasarkan analisis ayakan (besar butiran) batu-batuan kecil (Kerikil Jagung) tertahan pada ayakan $4,75 \mathrm{~mm}$. Sehingga dapat digolongkan kedalam kerikil halus dengan ukuran butiran $5 \mathrm{~mm} \leq 10 \mathrm{~mm}$.

Kerikil jagung digunakan sebagai bahan tambah dalam pembuatan paving block, dengan perbandingan berat pada komposisi campuran semen : pasir : kerikil jagung untuk bagian atas / kepala masing-masing A (1:1:0) / sebagai kontrol, B (1:1:1), C (1:1:1,5) dan D (1:1:2). Hal ini untuk mengetahui adanya perbedaan penggunaan kerikil jagung terhadap kuat tekan bata beton (paving block) sesuai dengan Standar Nasional Indonesia.

1. Apakah terdapat perbedaan kuat tekan antara bata beton yang menggunakan bahan tambah kerikil jagung dengan bata beton SNI mutu B (20 MPa)?

2. Pada perbandingan berapakah kerikil jagung sebagai bahan tambah campuran antara semen dan pasir mampu mencapai kuat tekan bata beton (paving block) optimum?

3. Apakah nilai kuat tekan bata beton (paving block) yang menggunakan kerikil jagung lebih tinggi dibandingkan dengan bata beton (paving block) mutu B SNI (20 $\mathrm{MPa})$ ?

4. Apakah kuat tekan bata beton (Paving Block) yang menggunakan Kerikil Jagung dapat memenuhi persyaratan mutu Paving Block Standar Nasional? 
Apakah paving block yang menggunakan bahan tambah kerikil jagung dengan komposisi campuran semen : pasir : kerikil jagung masing-masing $A(1: 1: 0), B(1: 1: 1), C$ (1:1:1,5), D (1:1:2) dapat memenuhi mutu B SNI 03-0691-1996 (Dengan persyaratan pengujian meliputi kuat tekan, ketahanan aus dan penyerapan air)?

\section{Pengertian Paving Block}

Bata beton (paving block) adalah suatu komposisi bahan bangunan yang dibuat dari campuran semen Portland atau bahan perekat hidrolis sejenisnya, air dan agregat dengan atau tanpa bahan tambah (aditif) lainnya yang tidak mengurangi mutu bata beton itu (SNI 03-0691-1996. Bata beton (paving block), Jakarta: BSN,1996, h.1)

\section{Syarat-syarat bata beton}

1. Sifat tampak, permukaannya rata, tidak terdapat retak-retak dan cacat, bagian sudut dan rusuknya tidak mudah dirapihkan dengan kekuatan jari tangan.

2. Ukuran, Bata beton harus mempunyai ukuran tebal minimun $60 \mathrm{~mm}$ dengan toleransi \pm $8 \%$. $(P=20 \mathrm{~cm}, \mathrm{l}=10 \mathrm{~cm}$, dan $\mathrm{t}=6,8,10 \mathrm{~cm})$

3. Sifat fisika

\begin{tabular}{|l|l|l|l|l|l|}
\hline \multirow{2}{*}{ Mutu } & \multicolumn{2}{|l|}{ Kuat tekan (Mpa) } & \multicolumn{2}{l|}{ Ketahanan Aus (mm/menit) } & $\begin{array}{l}\text { Penyerapan } \\
\text { air rata-rata (\%) }\end{array}$ \\
\cline { 2 - 5 } & Rata-rata & Min & Rata-rata & Min & \\
\hline A & 40 & 35 & 0,090 & 0,103 & 3 \\
B & $\mathbf{2 0}$ & $\mathbf{1 7 , 0}$ & $\mathbf{0 , 1 3 0}$ & $\mathbf{0 , 1 4 9}$ & $\mathbf{6}$ \\
C & 15 & 12,5 & 0,160 & 0,184 & 8 \\
D & 10 & 8,5 & 0,219 & 0,251 & 10 \\
\hline
\end{tabular}




\section{Bahan Penyusun Paving Block}

\section{a. Semen Portland}

Adalah semen hidrolis yang dihasilkan dari penggilingan klinker yang kandungan utamanya calcium silicate dan satu atau dua buah bentuk calcium sulfat sebagai bahan tambahan.

Sifat-sifat semen menurut pemakaiannya meliputi :

1. Hidrasi semen : reaksi antara komponen semen dan air.

2. Setting ( Pengikatan ) dan Hardening ( Pengerasan ): waktu mulai dari adonan terjadi pengikatan sampai mulai terjadi pengerasan.

3. Pengaruh Kualitas Semen Terhadap Kuat Tekan Beton: Kehalusan semen dan komposisi kimia.

\section{b. Agregat Halus ( Pasir)}

Merupakan agregat berupa pasir alam sebagai hasil desintegrasi alam dari batuan-batuan atau berupa pasir buatan yang dihasilkan oleh alat-alat pemecah batu yang mempunyai ukuran butir lebih kecil dari 4,8 mm (4,75 mm).

\section{c. Sirtu ( Pasir-Batu )}

Merupakan hasil letusan gunung api yang mengalami transportasi ke arah kaki lereng, maupun terbawa aliran sungai yang mengalir dari hulu dan diendapkan di bagian lembah / hilir sungai yang merupakan material endapan sungai / endapan limpah banjir.

Kerikil Jagung terdapat pada sirtu yang diendapkan di bagian hulu sungai karena didominasi oleh pasir yang mengandung batu-batuan kecil yang butirannya tertahan diatas ayakan $4,75 \mathrm{~mm}$ (ukurannya antara $5 \mathrm{~mm} \leq 10 \mathrm{~mm}$ ).

\section{- Kuat Tekan Bata Beton}

$$
\boldsymbol{\delta}=\mathbf{P} / \mathbf{L}
$$

$\delta=$ kuat tekan $(\mathrm{Kg} / \mathrm{cm} 2)$

$\mathrm{P}=$ beban tekan $(\mathrm{Kg})$

$\mathrm{L}=$ luas bidang tekan $(\mathrm{cm} 2)$

- Ketahanan Aus

$$
(\mathbf{A} \times 10) /(\text { BJ } \times \mathbf{I} \times \mathbf{W})
$$


$A=$ Selisih berat benda uji sebelum dan sesudah di aus (gr)
$B J=$ Berat jenis rata-rata lapisan kepala
$I=$ Luas permukaan bidang aus $\left(\mathrm{cm}^{2}\right)$
$W=$ Lamanya pengausan (menit)

\section{- Penyerapan Air}

$$
\begin{aligned}
& \text { ( A - B ) / B X } 100 \% \\
& \text { A = Berat Paving Block Kondisi Basah } \\
& \text { B = Berat Paving Block Saat Kering }
\end{aligned}
$$

Terdapat perbedaan kuat tekan Paving Block yang menggunakan bahan tambah kerikil jagung dengan yang tidak menggunakan kerikil jagung tehadap nilai kuat tekan Paving Block dengan mutu B SNI (20 Mpa)".

\section{METODA}

Pemeriksaan sifat kimia dan pengujian bahan dilaksanakan di Laboratorium Jurusan Teknik Sipil Fakultas Teknik UNJ. Penelitian ini dilaksanakan di Balai Penelitian Bahan dinas Perindustrian DKI Jakarta, yang terletak di jalan Jendral Suprapto Cempaka Putih, Jakarta Pusat. Pembuatan paving block dilakukan di Pabrik Cahaya Atap Sejati di Jl Patriot No. 111, Bekasi Barat. Penelitian ini dilaksanakan pada bulan Agustus - November 2009.

Metode penelitian yang digunakan adalah metode eksperimen di laboratorium dengan benda uji paving block yang menggunakan kerikil jagung sebagai bahan tambah terhadap nilai kuat tekan paving block berdasarkan SNI dengan komposisi campuran semen : pasir : kerikil jagung untuk bagian kepala masing-masing $A(1: 1: 0)$ / kontrol, $B(1: 1: 1), C(1: 1: 1,5)$ dan $D(1: 1: 2)$, sedangkan untuk lapisan bawah dengan perbandingan 1 pc : 8 ps, untuk menghasilkan bata beton mutu $B(20 \mathrm{Mpa})$.

\section{Variabel Penelitian}

1. Variabel bebas adalah bata beton dengan menggunakan bahan tambah kerikil jagung dengan komposisi campuran semen : pasir : kerikil jagung untuk bagian 
atas / kepala masing-masing $\mathrm{A}(1: 1: 0)$ / sebagai kontrol, $\mathrm{B}$ (1:1:1), C (1:1:1,5) dan $D(1: 1: 2)$.

2. Variabel terikat adalah bata beton (paving block) mutu B SNI.

Populasi dalam penelitian ini adalah bata beton yang menggunakan campuran air, agregat halus dan semen komposit yang diberi bahan tambah kerikil jagung dengan komposisi campuran semen : pasir : kerikil jagung untuk bagian atas / kepala masing-masing $A(1: 1: 0)$ I sebagai kontrol, $B(1: 1: 1), C(1: 1: 1,5)$ dan $D(1: 1: 2)$, sedangkan untuk lapisan bawah menggunakan semen dan pasir dengan perbandingan $1: 8$.

Teknik sampling dilakukan dengan membuat benda uji yang dikelompokkan menjadi 4 perlakuan, masing-masing 20 buah benda uji untuk setiap perlakuan.

Bata beton yang tidak menggunakan kerikil jagung dengan perbandingan 1 semen : 1 pasir diberi tanda A. Bata beton yang menggunakan kerikil jagung dengan perbandingan komposisi campuran semen : pasir : kerikil jagung masing-masing $B(1: 1: 1), C(1: 1: 1,5)$ dan $D(1: 1: 2)$.

Instrument Penelitian

1. Seperangkat alat untuk menguji kadar air, berat jenis dan penyerapan air, kadar lumpur, kadar organik, analisa agegat, dan indeks kekerasan agregat.

2. Seperangkat alat untuk pencetak paving block manual

3. Sepetangkat alat untuk pengujian ketahanan aus

4. Seperangkat alat tes kuat tekan

5. Lembar observasi

F. Prosedur Penelitian

1. Tahap persiapan

2. Tahap pemeriksaan bahan

3. Tahap pencampuran bahan paving block

4. Tahap pembuatan benda uji

5. Tahap pencetakan paving block 
6. Tahap pemeliharaan paving block

7. Tahap pengujian paving block.

Hipotesis Statistik

Ho: $\mu \mathrm{A}=\mu \mathrm{B}=\mu \mathrm{C}=\mu \mathrm{D}$

$\mathrm{Ho}=$ tidak terdapat perbedaan kuat tekan paving block yang menggunakan bahan tambah kerikil jagung pada lapisan atas / kepala untuk campuran A, B, C dan D.

\section{$\mathrm{H} 1: \mu \mathrm{A}<\mu \mathrm{B}<\mu \mathrm{C}<\mu \mathrm{D}$}

$\mathrm{H} 1$ = terdapat perbedaan kuat tekan paving block yang menggunakan bahan tambah kerikil jagung pada lapisan atas / kepala untuk campuran A, B, C dan D.

\section{Keterangan:}

$\mu A=$ nilai rata-rata kuat tekan paving block dengan menggunakan kerikil jagung pada perbandingan (1 pc : 1 ps : 0 kr.jg)

$\mu B=$ nilai rata-rata kuat tekan paving block dengan menggunakan kerikil jagung pada perbandingan (1 pc: 1 ps : $1 \mathrm{kr} . j \mathrm{~g}$ )

$\mu C=$ nilai rata-rata kuat tekan paving block dengan menggunakan kerikil jagung pada perbandingan (1 pc : 1 ps : $1,5 \mathrm{kr} . j \mathrm{~g}$ )

$\mu D=$ nilai rata-rata kuat tekan paving block dengan menggunakan kerikil jagung pada perbandingan (1 pc : 1 ps : 2 kr.jg)

\section{Teknik Analisis Data}

Berdasarkan hipotesis statistik di atas, untuk mengetahui ada tidaknya perbedaan kuat Tekan paving block dari 4 perlakuan digunakan uji Analisis Variansi (Anava). Sebelum data dianalisis, dilakukan pengujian persyaratan analisis data yaitu uji normalitas dengan uji Lilliefors dan uji homogenitas dengan uji Bartlett. Untuk mengetahui kadar optimum kerikil jagung yang digunakan sebagai bahan tambah, maka digunakan uji t rata-rata satu pihak.

\section{HASIL DAN PEMBAHASAN}

\section{A. Hasil Pengujian Bahan}


Tabel 4. Hasil Pengujian Agregat Halus dan Kasar

\begin{tabular}{|c|c|c|c|}
\hline Jenis pengujian & Pasir & $\begin{array}{l}\text { Kerikil } \\
\text { Jagung }\end{array}$ & Standar \\
\hline Kadar lumpur & $2.9 \%$ & $0,993 \%$ & SNI 03-1754-1990 \\
\hline Zat organik & $\begin{array}{c}\text { Kuning } \\
\text { muda }\end{array}$ & - & SNI 03-1755-1990 \\
\hline \begin{tabular}{ll} 
Berat & \multicolumn{1}{c}{ jenis dan } \\
penyerapan \\
- & BJ kering \\
- & BJ SSD \\
- & BJ Semu \\
- & Penyerapan air
\end{tabular} & $\begin{array}{c}2.440 \\
2.580 \\
2.840 \\
5.630 \%\end{array}$ & $\begin{array}{c}2.230 \\
2.370 \\
2.593 \\
6.270 \%\end{array}$ & SNI 03-1969-1990 \\
\hline Kadar air & $2.673 \%$ & $1.024 \%$ & SNI 03-1971-1990 \\
\hline Indeks kekerasan butiran & 1.867 & 27.54 & SNI 03-1756-1990 \\
\hline Modulus kehalusan & 3.297 & 6.271 & SNI 03-1968-1990 \\
\hline
\end{tabular}

\section{Rancangan Campuran Bata Beton}

Rancangan campuran bata beton ini dilakukan sesuai dengan data-data hasil uji pemeriksaan agregat, dengan semen yang digunakan adalah Semen Komposit, agregat halus berasal dari Bogor untuk campuran kuat tekan paving block yang direncanakan adalah mutu B SNI (20 MPa). Bagian badan perbandingan campuran paving block 1 semen : 8 pasir (perbandingan berat). Sedangkan untuk bagian kepala perbandingan campuran paving block 1 semen : 1 pasir (perbandingan berat) dengan tambahan kerikil jagung 1 ; 1,5 dan 2 (perbandingan berat). FAS yang digunakan pada campuran setiap perlakuan sama yaitu sebesar 0,5 . 


\section{Pembuatan Benda Uji}

Setelah proporsi campuran ditentukan kemudian dilakukan pengadukan bahan-bahan penyusun paving block, pengadukan dilakukan secara manual. Setiap pengadukan menghasilkan 22 benda uji (benda uji yang direncanakan 20 buah) untuk satu perlakuan, sehingga dilakukan 4 kali pengadukan. Pencetakan paving block dilakukan secara manual dengan memukul cetakan untuk memadatkan campuran. Pemukulan dilakukan sebanyak 10 kali untuk setiap pencetakan benda uji.

\section{Perawatan}

Setelah dilepas dari cetakan, paving block diletakkan ditempat yang terlindung sehingga tidak terkena sinar matahari langsung. Setelah satu minggu paving block dipindahkan ke tempat lembab dilaboraturium.

\section{Hasil Pengukuran Bata Beton (Paving block)}

Tabel 6. Ukuran Bata Beton (Paving Block)

\begin{tabular}{|l|l|l|l|l|}
\hline \multirow{2}{*}{$\begin{array}{l}\text { Proporsi } \\
\text { Kerikil Jagung } \\
(\text { kg) }\end{array}$} & \multicolumn{4}{|l}{ Ukuran Rata-Rata Bata Beton (Paving Block) } \\
\cline { 2 - 5 } & $\begin{array}{l}\text { Berat } \\
(\text { gram })\end{array}$ & $\begin{array}{l}\text { Panjang } \\
(\mathrm{cm})\end{array}$ & $\begin{array}{l}\text { Lebar } \\
(\mathrm{cm})\end{array}$ & $\begin{array}{l}\text { Tebal } \\
(\mathrm{cm})\end{array}$ \\
\hline Kontrol (1:1:0) & 2.187 & 20,020 & 10,020 & 6,050 \\
\hline $1: 1: 1$ & 2.200 & 20,021 & 10,013 & 6,007 \\
\hline $1: 1: 1,5$ & 2.220. & 20,011 & 10,017 & 6,009 \\
\hline $1: 1: 2$ & 2.250 & 20,012 & 10,011 & 6,012 \\
\hline
\end{tabular}


5. Hasil Pengujian Penyerapan Air

Tabel 7. Hasil Pengujian Penyerapan Air

\begin{tabular}{|l|l|l|}
\hline $\begin{array}{l}\text { Proporsi Kerikil Jagung } \\
(\mathrm{kg})\end{array}$ & $\begin{array}{l}\text { Penyerapan Air Rata-Rata } \\
(\%)\end{array}$ & $\begin{array}{l}\text { Jumlah } \\
\text { Sampel }\end{array}$ \\
\hline Kontrol (1:1:0) & 5,86 & 5 \\
\hline $1: 1: 1$ & 5.99 & 5 \\
\hline $1: 1: 1,5$ & 6,19 & 5 \\
\hline $1: 1: 2$ & 6,35 & 5 \\
\hline
\end{tabular}

\section{PENYERAPAN AIR}

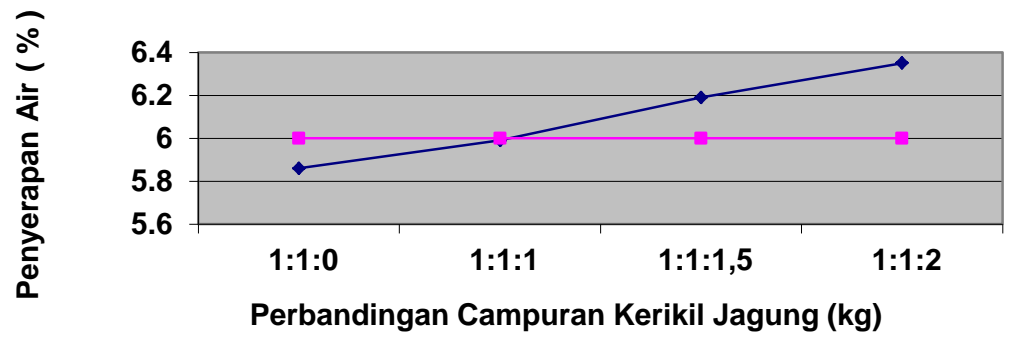

$\longrightarrow$ Penyerapan Air Rata-rat (\%)

$\longrightarrow$ - Penyerapan Air Rata-rata mutu B

\section{Hasil Pengujian Ketahanan Aus}

Tabel 8. Hasil Pengujian Ketahanan Aus

\begin{tabular}{|l|l|l|}
\hline $\begin{array}{c}\text { Proporsi Kerikil Jagung } \\
(\mathrm{kg})\end{array}$ & Ketahanan Aus Rata-Rata (mm/menit) & $\begin{array}{l}\text { Jumlah } \\
\text { Sampel }\end{array}$ \\
\hline Kontrol (1:1:0) & 0,136 & 5 \\
\hline $1: 1: 1$ & 0,132 & 5 \\
\hline $1: 1: 1,5$ & 0,142 & 5 \\
\hline $1: 1: 2$ & 0,144 & 5 \\
\hline
\end{tabular}




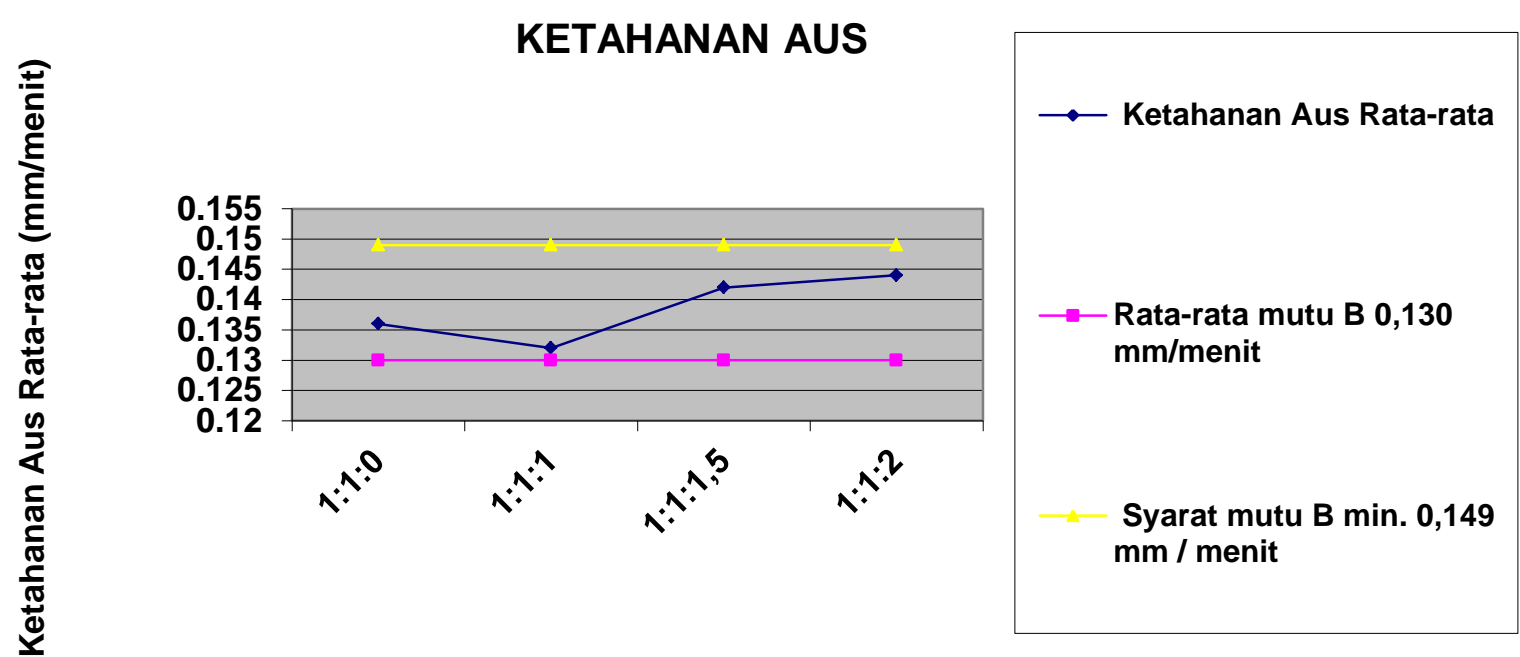

Perbandingan Campuran Kerikil Jagung (kg)

7. Hasil Pengujian Kuat Tekan Paving Block

Tabel 11. Hasil Pengujian Kuat Tekan Paving Block

\begin{tabular}{|l|l|l|}
\hline \multirow{2}{*}{$\begin{array}{l}\text { Proporsi Kerikil Jagung } \\
(\mathrm{kg})\end{array}$} & \multicolumn{2}{|l|}{ Nilai Kuat Tekan Rata-Rata } \\
\cline { 2 - 3 } & Kg/cm & MPa \\
\hline Kontrol (1:1:0) & 201,30 & 19,76 \\
\hline $1: 1: 1$ & 212,33 & 20,82 \\
\hline $1: 1: 1,5$ & 192,10 & 18,84 \\
\hline $1: 1: 2$ & 185,70 & 18,21 \\
\hline
\end{tabular}

KUAT TEKAN PAVING BLOCK
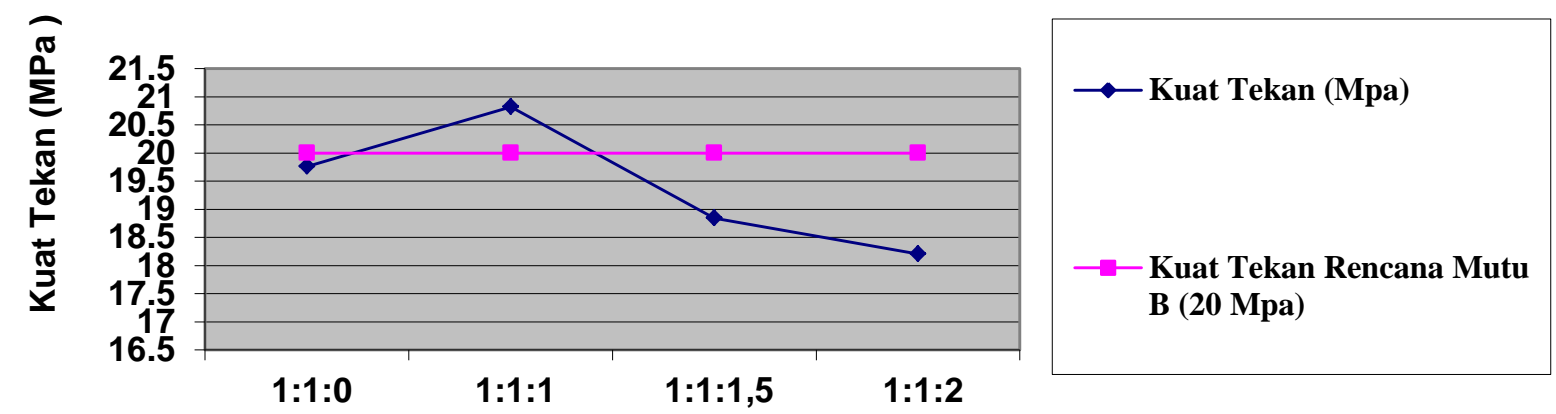

Perbandingan Campuran Kerikil Jagung (kg)

Jurnal Menara Jurusan Teknik Sipil FT.UNJ

Volume VI - No.1 - Januari 2011 


\section{Uji Normalitas}

Tabel 12. Hasil Uji Normalitas Data

\begin{tabular}{|l|l|l|l|}
\hline Paving Block & L $_{\text {hitung }}$ & $\mathbf{L}_{\text {tabel }}$ & Kesimpulan \\
\hline Kontrol (1:1:0) & $\mathbf{0 , 0 9 1}$ & $\mathbf{0 , 2 9 4}$ & Lhit < Ltabel = Normal \\
1:1:1 & $\mathbf{0 , 0 3 6}$ & $\mathbf{0 , 2 9 4}$ & Normal \\
$1: 1: 1,5$ & 0,058 & 0,294 & Normal \\
$1: 1: 2$ & 0,003 & 0,294 & Normal \\
& & & \\
\hline
\end{tabular}

\section{Uji Homogenitas}

Tabel 13. Hasil Uji homogenitas Kuat Tekan Paving Block

\begin{tabular}{|l|l|l|l|l|l|}
\hline $\mathrm{S}^{2}$ Gabungan & $\log \mathrm{S}^{2}$ & $\mathrm{~B}$ & $\mathrm{X}_{\text {Hitung }}$ & $\mathrm{X}_{\text {Tabel }}$ & Hasil \\
\hline 0.273 & -0.564 & -20.304 & 7,503 & 11,3 & $\begin{array}{l}\mathrm{X}_{\text {Hitung }}^{2} \mathrm{X}_{\text {Tabel }}^{2} \\
\text { Data Homogen }\end{array}$ \\
\hline
\end{tabular}

\section{Keterangan :}

$\mathrm{S}^{2}$ Gabungan = Varians gabungan dari kelompok A, B, C, D, dan E

B = Harga besaran diuji kuadrat

$\mathrm{X}^{2} \quad=$ Chi-kuadrat

\section{Pengujian Hipotesis}

Tabel 14. Hasil Uji Analisa Varians

\begin{tabular}{|l|l|l|l|l|l|}
\hline Daftar Varians & dk & JK & KT & F Hitung & F $_{\text {Tabel }}$ \\
\hline Rata-rata & 1 & 15062,16 & 15062,16 & 47,41 & 4,38 \\
Antar kelompok & 3 & 38,75 & 12,92 & & \\
Dalam kelompok & 36 & 9,81 & 0,2725 & & \\
\hline Total & 40 & 15110,72 & & & \\
\hline
\end{tabular}




\section{Keterangan :}

$\mathrm{Dk}=$ Derajat Kebebasan

$\mathrm{JK}=$ Jumlah Kuadrat

KT = Kuadrat Tengah

Dari tabel diatas dengan dk pembilang 3 , dk penyebut 36 dan peluang 0,99 (taraf nyata $\alpha=0,01$ ) didapat Ftabel $=4,38$ dan Fhitung $=47,41$. Ternyata FHitung $>$ FTabel maka HO ditolak. Kesimpulannya terdapat perbedaan antara kuat tekan paving block yang menggunakan kerikil jagung sebagai bahan tambah dengan perbandingan antara semen : pasir : kerikil jagung masing-masing $A(1: 1: 0), B(1: 1: 1), C$ (1:1:1,5), D (1:1:2).

Tabel 15. Tabel Uji T Test

\begin{tabular}{|c|c|c|c|c|c|c|}
\hline $\begin{array}{l}\text { Proporsi pc : ps : } \\
\text { kr.jg }\end{array}$ & $\begin{array}{l}\text { Standa } \\
\mathbf{r} \\
\text { deviasi }\end{array}$ & $\begin{array}{l}\text { Nilai } \\
\text { rata- } \\
\text { rata }\end{array}$ & $\begin{array}{l}\mathbf{t} \\
\text { hitung }\end{array}$ & $\mathbf{t}_{\text {tabel }}$ & Hipotesis & $\begin{array}{l}\text { Keteranga } \\
\text { n }\end{array}$ \\
\hline $1 \mathrm{pc}: 1 \mathrm{ps}: 0 \mathrm{kr} . \mathrm{jg}$ & 0,479 & 19,76 & $-1,6$ & 2,82 & $\begin{array}{l}\mathrm{H}_{0} \\
\text { diterima }\end{array}$ & Memenuhi \\
\hline $1 \mathrm{pc}: 1 \mathrm{ps}: 1 \mathrm{kr} . \mathrm{jg}$ & 0,332 & 20,82 & 7,45 & 2,82 & $\mathrm{H}_{0}$ ditolak & Melebihi \\
\hline $1 \mathrm{pc}: 1 \mathrm{ps}: 1,5 \mathrm{kr} . j \mathrm{~g}$ & 0,208 & 18,84 & $\begin{array}{l}- \\
16,5 \\
7\end{array}$ & 2,82 & $\begin{array}{l}\mathrm{H}_{0} \\
\text { diterima }\end{array}$ & Memenuhi \\
\hline $1 \mathrm{pc}: 1 \mathrm{ps}: 2 \mathrm{kr} . j \mathrm{~g}$ & 0,073 & 18,21 & $\begin{array}{l}- \\
77,8 \\
3\end{array}$ & 2,82 & $\begin{array}{l}\mathrm{H}_{0} \\
\text { diterima }\end{array}$ & Memenuhi \\
\hline
\end{tabular}

Dari tabel diatas diperoleh $\mathrm{t}$ hitung $>\mathrm{t}$ tabel yang berarti $\mathrm{H} 0$ ditolak. Kesimpulannya: ratarata kuat tekan paving block yang menggunakan perbandingan campuran $1 \mathrm{pc}: 1 \mathrm{ps}: 1 \mathrm{kr}$. Jagung memenuhi syarat kuat tekan paving block mutu B (20 Mpa). Sedangkan yang menggunakan perbandingan campuran $1 \mathrm{pc}: 1 \mathrm{ps}: 0 \mathrm{kr}$.jagung, $1 \mathrm{pc}: 1 \mathrm{ps}: 1,5 \mathrm{kr}$. Jagung, 1 pc : 1 ps : 2 kr.jagung didapat hasil yang sebaliknya. 


\section{B. Keterbatasan Penelitian}

1. Pembuatan benda uji masih secara manual sehingga pemadatan benda uji tidak semuanya sama.

2. Pembuatan benda uji yang sedikit (kurang dari 30 benda uji) yang dapat menyebabkan kesalahan statistik.

3. Bahan material yang masih berfariasi sehingga hasil uji tekan dapat di generalisasikan.

4. Pengukuran dan kalibrasi alat tidak selalu tepat, sehingga perbedaan pengukuran pada tiap-tiap benda uji tidak sama.

5. Tidak dilakukan pengujian Natrium Sulfat untuk menguji keawetan.

\section{KESIMPULAN}

Berdasarkan hasil penelitian terhadap paving block dengan pengunaan kerikil jagung sebagai bahan tambah,maka dapat disimpulkan sebagai berikut :

1. Nilai kuat tekan rata-rata paving block tanpa menggunakan bahan tambah kerikil jagung $\mathrm{A}$ (1:1:1) sebesar 19,76 MPa, sedangkan Paving block yang menggunakan kerikil jagung dengan perbandingan campuran semen : pasir : kerikil jagung $B$ (1:1:1), C (1:1:1,5) dan D (1:1:2) berturut-turut sebesar 20,82 MPa, 18,84 Mpa dan 18,21 Mpa sehingga termasuk dalam mutu B. Maka dapat disimpulkan bahwa nilai rata-rata kuat tekan paving block memenuhi mutu SNI 03-0691-1996. Dengan nilai optimum kerikil jagung yang dapat digunakan pada paving block sebagai bahan tambah adalah paving block $B$ yaitu pada perbandingan campuran 1 semen : 1 pasir : 1 kerikil jagung dengan kuat tekan rata-rata 20,82 Mpa.

2. Penyerapan air rata-rata paving block $A(1: 1: 0)$ sebesar $5,86 \%$, sedangkan paving block dengan perbandingan campuran semen : pasir : kerikil jagung $B(1: 1: 1), C$ $(1: 1: 1,5)$ dan $D(1: 1: 2)$ menghasilkan penyerapan air rata-rata berturut-turut sebesar 5,99\%; 6,19\% dan 6,35\%. Penggunan kerikil jagung dapat menambah penyerapan air dan berdasarkan nilai rata-rata penyerapan air tersebut maka penyerapan air paving block A dan B termasuk dalam mutu B. Sedangkan penyerapan air paving block $C$ dan $D$ termasuk dalam mutu C. Menurut SNI 030691-1996, penyerapan air maksimal untuk mutu B adalah sebesar 6\%. 
3. Nilai ketahanan aus rata-rata paving block $A$ (1:1:0) menghasilkan nilai ketahanan aus rata-rata sebesar $0,136 \mathrm{~mm} /$ menit yang memenuhi mutu $B$. Ketahanan aus pada paving block dengan perbandingan campuran semen : pasir : kerikil jagung $B$ (1:1:1), $C(1: 1: 1,5)$ dan $D(1: 1: 2)$ menghasilkan nilai ketahanan aus rata-rata berturut-turut sebesar $0,132 \mathrm{~mm} /$ menit; $0,142 \mathrm{~mm} / \mathrm{menit}$ dan $0,144 \mathrm{~mm} / \mathrm{menit}$ yang memenuhi mutu B. Dapat disimpulkan bahwa mutu terbaik dengan nilai rata-rata ketahanan aus terendah dihasilkan oleh paving block $\mathrm{B}$ yaitu paving block dengan perbandingan campuran 1 semen : 1 pasir : 1 kerikil jagung 